\title{
Floor of the Mouth Neoplasm
}

National Cancer Institute

\section{Source}

National Cancer Institute. Floor of the Mouth Neoplasm. NCI Thesaurus. Code C4401.

A benign or malignant neoplasm that affects the floor of the mouth. 